\title{
Introduction: Reclaiming Feminism: Gender and Neoliberalism
}

\author{
Andrea Cornwall, Jasmine Gideon and Kalpana Wilson*
}

Even the most devoted believers in the neoliberal paradigm will have had their convictions shaken in recent times, as the world's markets have played havoc with their faith. For those who have long questioned the purported benefits of neoliberal economic policies and highlighted their injurious consequences, it comes as little surprise that this 'grab-bag of ideas based on the fundamentalist notion that markets are selfcorrecting, allocate resources efficiently and serve the public interest well', as Stiglitz (2008) well describes neoliberalism, is in freefall. The focus of this IDS Bulletin is therefore particularly apposite at a time when much-cherished axioms are being re-inspected and where new possibilities and directions are so badly needed.

Contributors to this IDS Bulletin add to a growing, vibrant debate about the past, present and future of Gender and Development. This IDS Bulletin arises from a conference of the same title that was held at the Institute of Development Studies in Brighton in July 2007 in collaboration with the Development Studies Programme at Birkbeck College, London University, under the auspices of the Pathways of Women's Empowerment Research Programme Consortium. ${ }^{1}$ The conference brought together around 50 participants from around the world to reflect upon the relationship between feminisms and neoliberalism, in the context of international development. It set out to provoke reflection on the now ubiquitous notions of 'empowerment' and 'agency' within neoliberal development discourses on gender. And it sought to raise broader questions about the politics and political economy of Gender and Development.

The conference brought together women engaged in movements taking place outside the framework of 'development' with women endeavouring to shape the development enterprise from within. Debates explored how concepts and principles that emerged out of feminist analysis and women's collective struggles, and shaped Gender and Development thinking and practice, have been appropriated and transformed by neoliberal development institutions and discourses. Lively discussions explored the prospects for reclaiming these ideas and using them to reframe and revitalise feminist engagement. They went far beyond mere critique, highlighting submerged or otherwise obscured issues, theorising feminist interventions and exploring new directions for feminist praxis within and beyond 'development'.

\section{Gender, feminism and neoliberalism}

The term 'neoliberalism', as Maxine Molyneux (2008) reminds us, is so commonly used, it has become a catch-all for a multitude of things - a 'grab-bag', as Stiglitz evocatively calls it. For many, it is synonymous with a set of economic policy prescriptions associated with the 'Washington Consensus'; for others, it evokes something much more diffuse and all encompassing, a socioeconomic system in its own right. Despite ongoing debate around definitions, there is a general agreement that we are now experiencing a different phase of neoliberalism to that of the 1970s and 1980s where the emphasis was on 'market fundamentalism'. Since the 1990s, revision of some policies has led to the emergence of what has commonly been labelled 'postWashington Consensus' or 'neoliberalism with a human face' (Molyneux 2008).

The literature that emerged in the early 1990s showing the gender blindness of neoclassical economics and the markedly negative effects of neoliberal policies on women (see, for example, Elson 1992; Sparr 1995) has been complemented in recent years by a new wave of studies which 
document some of the perverse consequences of a swing of the pendulum as development agencies have turned their attentions to women (see, for example, Batliwala and Dhanraj 2004). A new direction emerging in recent critical work is a focus on the normative dimensions of development programmes, and, in particular on the implicit or explicit heteronormativity that lies at the heart of the development industry (Bedford 2005; Griffin 2006). A number of studies highlight the extent to which the anti-poverty programmes that have arisen in part to mitigate the effects of neoliberal economic reforms have a marked tendency to reproduce and reinforce deeply conservative notions of womanhood and of women's role within the family (Molyneux 2006). Others explore the confluence of influences, including the scale of the influence exerted by neo-conservative elements within foreign and national institutions, that have come to play a decisive role in shaping policy responses in many countries (see contributions by Bradshaw and Bedford, this IDS Bulletin).

Paradoxically, while those in the mainstream development institutions who have championed neoliberal economic policies have never really been able to grasp the concept of gender, they appear to have acquired a growing interest in women. Where feminists once highlighted the systematic institutional bias against women in economic policy, we now see institutions like the World Bank and the Department for International Development (DFID) lauding the importance of giving women more of a role in economic development. Women become, in the language of DFID's glossy Gender Equality at the Heart of Development (2007), a 'weapon' in the fight against poverty, as the World Bank proclaims that investing in women entrepreneurs is 'Smart Economics' (Buvinic and King 2007). The scene has shifted. Women are no longer on the sidelines, or ignored altogether. And yet when we take a closer look at the way in which women come to be represented, it becomes evident that what appears may be far from what feminists might have desired. Hawkesworth evokes the tenor of the way women come to be represented in these new narratives:

Women are simultaneously hailed as resourceful providers, reliable micro-entrepreneurs, cosmopolitan citizens, and positioned as 'disposable domestics', the exploited global workforce, and as displaced, devalued and disenfranchised diasporic citizens.

(Hawkesworth 2006: 202)

Neoliberal policies have given rise to what critics call a 'feminisation' of labour, accompanied by a deterioration of working conditions - casualisation, flexibilisation, violation of international labour standards and low wages (Moghadam 2005). Yet the story of the effects of the process of globalisation that has accompanied the implementation of neoliberal policies is rather more complex than this. It becomes important to distinguish different elements of the picture, to disentangle neoliberalism from globalisation and from, as we go on to explore, neo-conservatism. It is here that some of the challenges arise for feminist analysis. For a start, neoliberal policies have not been uniformly bad for women - and for some women, policies such as market liberalisation may have indeed contributed to their pathways of empowerment. After all, as Diane Elson has pointed out, 'markets do not always operate against the interests of women' (1992: 51). It is important not to overlook the empowering dimensions of the new forms of work that have become available to women - including mobilisation in struggles for labour rights in the new globalised industries (Kabeer 2008). Yet as Jasmine Gideon's article in this IDS Bulletin on Chile suggests, it is vital to look at the bigger picture and at other neoliberal reforms which have given rise to effects that compound the impact of the informalisation of work, perhaps most significant amongst them the privatisation of care.

As Maitrayee Mukhopadhyay reminded us at the conference, care needs to be taken not to conflate neoliberalism with neo-conservatism. After all, she pointed out, 'neoliberalism in its pristine form has destabilised an order context of patriarchy and has stressed choice'; indeed it is this 'shared pursuit of choice' that characterises one of the points of convergence between feminism and neoliberalism. Herein lies another complexity for feminist analysis. Where neoliberalism and neo-conservatism converge, some of the more potentially liberating elements of neoliberalism become suffocated by appeals to tradition and the dampening normativity of highly conservative religious institutions. However, the discussions at the workshop also underlined the need to go beyond a dichotomisation of neoliberal interventions emphasising choice and destabilising patriarchy and patriarchal social structures rooted in 
pre-capitalist social formations. They explored the ways in which, in a variety of contexts, the practice of neoliberalism draws upon, incorporates and reinforces these existing patriarchal relationships of power and selectively re-emphasises patriarchal social norms. While for some participants neoconservative social movements were seen as a reaction to the withdrawal of the state and the undermining of security, others highlighted a more symbiotic relationship in which the two were highly compatible, finding common ground in the recasting and reinforcing of patriarchies. This becomes evident in a number of contributions to this IDS Bulletin.

These challenges to feminist engagement come at a time when the wider changes wrought by the impact of neoliberal economic policies and ideology have taken their toll on feminist activism. Hawkesworth notes that neoliberal policies 'cut back the very aspects of the state that feminist activists seek to build up' (2006: 121) and were accompanied by a gendered reconfiguration of responsibilities between citizens and the state. Once the burden of social service provision had been shifted decisively onto poor women and community level 'civil society organisations', 'civil society' itself was cast in an ever more significant role: as an all-purpose intermediary which would simultaneously keep the state in check, make up for its shortcomings, use proximity to 'the poor' to help them to help themselves, and represent the masses who could not speak for themselves. As this implies, 'civil society' has increasingly come to be regarded by development agencies and donors as a key space for intervention and control.

Donor funding for non-governmental organisations (NGOs) on a massive scale has led to women's movements and organisations in many countries undergoing a process of depoliticising 'NGOisation' (Alvarez 1998) - with damaging consequences for the mobilisation of women, as Islah Jad (this IDS Bulletin) shows. This has contributed to a lack of political muscle, as once-active feminist organisations become (or are displaced by) increasingly depoliticised service providers, reliant on contracts from the state or grants from the development industry. As the 'invited spaces' of neoliberal governmentality have come to displace and be used to delegitimise the 'invented spaces' (Miraftab 2004) of social mobilisation, 'empowerment' has come to be associated with individual selfimprovement and donor interventions rather than collective struggle (Sardenberg, this IDS Bulletin).

\section{Contesting 'empowerment'}

Contemporary development policy narratives speak not just of women, but of the term that became a rallying cry for southern feminists in the early 1990s: 'women's empowerment'. With this has come a series of narratives about women as more efficient and responsible that accentuate women's compliance with normative expectations. Women appear in these narratives as hard-pressed mothers struggling for the wellbeing and betterment of their families.

Development is presented as giving women a welldeserved chance to improve their circumstances, so as to be able to benefit their families, communities and their nations. The World Bank's Buvinic and King (2007) for example, offer a neat chain of causalities that begins with empowering women and girls and leads to economic growth and poverty reduction. Similar stories are told in the promotional materials of a number of agencies. Words like 'agency' and even 'power' come to be appropriated for this purpose (see, for example, Alsop 2005). Indeed, contributors to this IDS Bulletin highlight how, along with 'empowerment', an entire lexicon of terms that were once associated with feminist activism have come to be laden with the attributed meanings of development agencies.

Srilatha Batliwala, author of a foundational 1994 report that helped to put 'women's empowerment' on the development map, reflects on how the term 'empowerment' has been eviscerated of its original political content (Batliwala 2007). As Kalpana Wilson argues, 'agency' has become a particularly troubling object for neoliberal appropriation. Reduced to the exercise of individual preference - or even to the acquisition of assets, in the World Bank's framework - 'agency' joins 'choice' in a coupling of concepts that permits little scope for any talk about power, inequities or indeed any structural constraints at all.

Some of this becomes evident when we look more closely at the kinds of definitions of 'empowerment' that different organisations are using. According to the World Bank, empowerment is 'the process of enhancing an individual's or group's capacity to make purposive choices and to transform these choices into desired actions and outcomes' (Alsop et al. 2005: 120). Contrast this with the definition developed by Indian feminist NGO Nirantar, cited in Chakravarti's contribution to this IDS Bulletin:

... the ability to define the change for themselves, negotiate change, understand and challenge 
injustice and inequity, and act towards the achievement of strategic goals that address issues of women's status/position. [p14]

It becomes apparent that as it has come to be used by the World Bank and other mainstream development institutions, the term 'empowerment' has come to contain little by way of family resemblances to what feminist NGOs such as Nirantar understand it to mean (Batliwala 2007). It comes to be reduced to what Cornwall (2007) calls 'empowerment lite', accommodating women within rather than challenging or transforming the existing social order. Writing in this IDS Bulletin, Cecilia Sardenberg observes

Without a significant change in their sustaining models [...] development agencies merely adopt the term 'empowerment' and not the approach it originally entailed. Transplanted into the liberal framework of modernisation theory, the notion of empowerment elaborated by feminists from the South could not survive as a transformative, revolutionary concept [p21]

Sardenberg draws a distinction between 'liberal' and 'liberating' empowerment, contrasting representations of empowerment as a gift that can be given with those that locate empowerment in deeply contested processes of structural change in power relations. At the heart of 'liberal' empowerment, Sardenberg argues, lies a consensual version of the kinds of changes that will bring about empowerment, one that obscures the profound issues of power at stake and the conflicts that may be inevitable if real change is to happen. She cites Jorge Romano:

... the empowerment evoked by banks and multilateral and bilateral development agencies, by different governments, and also by NGOs, has also been used primarily as an instrument of legitimation for them to continue doing, in essence, what they have always done. But now with a new name: empowerment ... A typical situation of transformism (gattopardismo): to appropriate and distort the new, to guarantee the continuity of dominant practices. Adapting to the new times, changing 'everything' so as to change nothing. (Romano 2002: 10, Sardenberg's translation from the original Portuguese) [p21]

Neoliberal empowerment narratives not only empty 'empowerment' of any contentious political content, they also make money - microcredit loans, conditional cash transfers, enhanced access to markets and livelihood assets - the magic bullet, as if that were somehow enough to effect wholesale transformations in women's lives. As Charmaine Pereira, reflecting on the package of interventions promised in the Nigerian Economic Empowerment and Development Strategy, notes:

The assumption here is that a package that brings together single measures to address women's concerns will, in and of itself, bring about empowerment. This is a far cry from challenging the ideologies that justify gender inequality, changing prevailing patterns of access to and control over resources (as opposed to providing the resources themselves), and transforming the institutions that reinforce existing power relations. [p45]

That a concern for women finds its way into national economic policies is, of course, some mark of success. Indeed one might think surely feminists ought to be glad to see that the issues that they fought so hard to get onto the agenda are now appearing in the pronouncements of development agencies with such regularity and apparent commitment. Yet, if we look at the shape that this success has taken, or been translated into, a positive reading of development's absorption of the language of 'gender' is harder to sustain. Josephine Ahikire talks of the 'apparent divergence between the terms gender and feminism' in Uganda. It has come to be the case in many contexts that 'gender' has come to gain a softer, more conciliatory touch, its use a device to distance the user from association with 'feminism'. And when 'gender' is used by mainstream agencies to talk about women, as it generally is, the women who come into view are not everywoman. Rather, the predominant representation of women is as those who lack agency and opportunities. One of the problems, as Ahikire points out, is that the:

... broad motive to highlight the plight of women, the fact that women tend to be the worst victims of poverty, wars, disease (such as the HIV/AIDS pandemic) unfortunately translates into a field of 'lamentations' that may in the end carry a critical anti-feminist message. [p30]

A consequence, Ahikire goes on to highlight, is that the language of vulnerability and marginalisation that 
has come to be associated with 'gender', runs the risk of infantilising women, lumping them together with children as the deserving objects of intervention.

It is precisely the nature of the response to the victim narrative that a number of the contributors to this collection highlight as one of the contradictions produced by the convergence of Gender and Development and neoliberal thinking and practice. Any vestige of a more dignified way of talking about women who are living in poverty falls away. The stereotypical woman that these discourses evoke is always heterosexual, usually either with an abusive or useless husband or a victim of abandonment struggling to survive as a female-headed household She is portrayed as abject and at the same time as eager to improve herself and her situation if only she could be 'empowered'.

\section{The new 'good woman'}

One of the thorniest challenges for feminist engagement with contemporary development policy narratives arises from this. It is that it is no longer possible to complain that women are absent from these narratives. Rather, it is the way in which women are represented and the implications in terms of policy responses, and also in terms of the subjects that the practices associated with these discourses produce, that has become part of the problem. Drawing on recent studies of self-help groups in India, Chakravarti shows the extent to which the discourses associated with them are:

... creating new norms for the 'good woman' in a neoliberal framework: one who saves and repays regularly, puts pressure on other group members to do similarly ... and is committed to the welfare of the family. [p15]

She notes that the very fact that men are reportedly happy with women's participation is 'in keeping with the reality that this engagement in no way challenges unequal power relations within the family'. One of these studies, carried out by feminist NGO Nirantar, found that it was precisely 'family values' that made women better bets for microfinance. An official promoting microcredit is cited as explaining:

women can be located easily ... they cannot run away, leaving their homes; they can be persuaded to repay more easily as they feel shame more quickly and consider non-repayment a matter of family honour. [p15]

The phenomenon of women's greater 'efficiency' in relation to men has become ubiquitous in Gender and Development accounts. It is the focus of a multitude of neoliberal policy prescriptions. As Kalpana Wilson argues in this IDS Bulletin, it is inseparable from the structures and practices of patriarchies operating at both material and ideological levels. This is the case because it is based on both women's greater responsibility for meeting children's needs and their tendency to expend less resources (in terms of both leisure time and luxury consumption) on themselves. As Wilson suggests:

... where women have waged struggles themselves, these struggles have frequently been accompanied by a questioning of the precise complex of gender relations which make women supposedly more 'efficient' producers/workers [p89]

While neoliberalism may be archetypically associated with the individual as atomistic rational agent, its roots lie in liberal theory, which has always excluded women from this notion of individuality. So perhaps we should not be surprised if, as several of the contributions to this IDS Bulletin demonstrate, neoliberalism subsumes women into an image of the protective mother who will translate any gains from the market into the means for household survival, and will be prepared to make unlimited personal sacrifices to provide the household with a safety net against the ravages of neoliberal macroeconomic policies. Ideologically, this works to re-embed women within familial relations. As a result, the family becomes a key site for the exercise of neoliberal governmentality.

Sarah Bradshaw and Kate Bedford (this IDS Bulletin) draw attention to the extent to which Latin American social policies both presuppose and reinforce a model of the family that has the heterosexual couple at its heart. Bradshaw shows how contemporary social protection programmes divert attention away from the female householdhead to the nuclear family. Bedford, focusing on a World Bank-funded family strengthening programme in Argentina, explores the extent to which programmes like these are reinscribing and renaturalising a particular form of heterosexual 
intimate and familial relations. 'Good mothers' come to be coupled with 'responsible men' as 'partners', as the state retreats further from supportive social provision.

Bedford shows the defining role that was played by the bank in the programme, naturalising private provision of care within the family as 'an efficient and empowering way to resolve tensions between paid and unpaid labour'. The net result, she contends, is reduced policy space for domestic violence, greater policy openings for conservative religious organisations concerned with 'the family' and difficulties arguing for social provision outside the family, such as institutionalised childcare. She highlights the ironies of the extent to which an articulation of the problem that seemed to address long-standing feminist concerns led to a solution that few feminists might agree with:

After all, many feminists wanted men to stop shirking domestic work and International Financial Institutions to take care seriously. However we did not necessarily want childcare erased as a policy priority, replaced by more shared (but still privatised) caring labour within couples ... [or] poor men held responsible for women's poverty. [p64-5]

\section{Revisiting feminist engagements with development}

Feminists have tended to be more reflexive than many of those engaged with the development enterprise, whether from 'within' or 'outside'. The landmark volume Feminist Visions of Development (Jackson and Pearson 1998) revisited theoretical contributions made by feminist researchers over the course of the 1980s, reviewing and repositioning their insights. Ten years later, Feminisms in Development: Contestations, Contradictions and Challenges (Cornwal et al. 2007) takes stock of some of the unexpected hurdles and contradictions that arose as the Gender and Development agenda was taken up by development agencies. This collection continues this work of revisiting feminist engagements with development. It complements the focus in both of these earlier volumes on exploring whether certain axioms that have become part of the Gender and Development field have stood the test of time and travel to other contexts, with a critical gaze at the development industry itself.

What emerges from many of the contributions to this collection is a sense of unease with the extent to which Gender and Development discourses have lent themselves to appropriation - and with what stories they tell about women and their relationships with men and with each other.

A number of contributors go further to signal deeprooted problems with some of the very axiomatic assumptions that have been so pivotal a part of the Gender and Development discourse. Kate Bedford, for example, reveals the heteronormativity that resides at the very heart of the notion of 'gender equality': an ideal of equality between women and men that speaks about relations within a heterosexual couple, to the exclusion of other gender relations or other kinds of partnership. Other kinds of relationships fall out of the frame. Penny Vera-Sanso (this IDS Bulletin) highlights the extent to which narratives about women's economic autonomy may misconstrue precisely the power that women may exercise over the household purse, as well as the basis for solidaristic relations within the household.

What emerges from this is a more fundamental critique of Gender and Development. It echoes earlier critiques of the dominance of feminisms that obscured other dimensions of difference and projected preoccupations amongst a particular group of people in one particular context onto all other people and places (see for example, Mohanty 1991; Ogundipe-Leslie 1994). Part of the problem is that the field of development is largely so devoid of historical or contextual understanding, it is in some respects unsurprising that Gender and Development narratives have acquired the same ring of universality to them. While feminist theory and practice over the last three decades and more has been systematically critiqued, re-envisioned and reconstructed, little of the dynamic debate about 'race', class, imperialism and other interrelated structural inequalities seems to have permeated the field of Gender and Development. At best, we hear talk about 'intersectionality', a concept that appears to have gathered few adherents. And so, many of the prescriptions and practices associated with Gender and Development continue to be underpinned with universalistic assumptions about women, men and gender relations.

The cultural specificity of these assumptions is becoming ever more apparent. In her article Penny Vera-Sanso argues in the context of poor households 
in South India that the representations of women that appear in narratives of economic empowerment profoundly misconstrue the nature of women's economic lives in such contexts. Vera-Sanso revisits some of the presuppositions informing Gender and Development narratives of women's subordination within conjugal relationships, raising questions about the extent to which prevailing wisdoms about women and money make sense in the particular context of poor households in South India. Examining the social and economic constraints experienced by men in these households, she highlights the tendency of this work to essentialise poor men as 'selfish and irresponsible' - an approach which, as several other contributors suggest, has been incorporated into a neoliberal moral narrative of 'deserving' poor women and their 'undeserving' male counterparts. VeraSanso's article reminds us of the cultural contingency of these notions, and highlights just how out of kilter they may be with women's lived realities.

Other contributors to this IDS Bulletin emphasise the specifically liberal capitalist framework underpinning these assumptions - see for example Sardenberg's contrast between 'liberal' and 'liberating' notions of empowerment - and the experiences cited by Jad and Chakravarti here also highlight the idea of differences which are primarily political. As Charmaine Pereira commented at the workshop, 'we need to be wary of our critiques being essentialised as "culture"'. Further, feminists from the South have highlighted the tendency in some recent Gender and Development work to use the notion of cultural specificity and 'difference' to delegitimise feminist projects of radical social transformation as 'inauthentic'. Kalpana Wilson argues here that such accounts are consistent with the neoliberal discursive framework, in which the exercise of 'agency' originally brought centre stage by feminists like Mohanty (1991) - has been reduced to strategies for survival in a world constrained by the parameters of the neoliberal model. Women and movements who challenge these parameters are rendered invisible.

\section{Reclaiming feminism}

The struggles for interpretive power that characterised feminist engagement with development in the 1990s largely took shape around the advancement of positions around which to build a consensus, as a bridgehead for policies that seek to address gender inequities. It can be argued that the institutionalised pull towards the promotion of consensus within the development establishment is in itself a critical limitation for activism, because it acts as a fire blanket, putting out any spark. Josephine Ahikire comments on the extent to which Gender and Development might be seen as a 'field with no competing discourses': amidst such apparent agreement, there is little scope for constructive disagreement.

What this collection attests to is the existence of substantive disagreements amongst those who engage as feminists with development, and the value of airing and debating differences of perspective amongst those who are positioned differently in relation to the development enterprise. The analyses put forward by the contributors to this collection affirm the importance of reflexive critique as a vital part of feminist engagement with development. By signalling the limits of existing frames and interventions, they can help to highlight issues that are otherwise obscured, as well as bring into question taken-for-granted assumptions that may be misleading. The foundational feminist writings that gave rise to Gender and Development in the late 1970 s still contain a lot that resonates with the situation of many women in the contemporary world. But three decades of feminist research and theorising have shown that the frame they provided through which to view the world does not always fit. Over this period, new concepts and tools have become available, and new emphases have emerged within the field of feminist and gender studies that change the way in which contemporary analysts approach some of the issues with which Gender and Development is concerned. It is only recently, for example, that researchers have had the conceptual tools to speak about heteronormativity (Jackson 2006; Bedford 2005; Griffin 2006).

At the same time, as feminist ideas have been taken up and transformed by the development industry, insights that were once nuanced and contextualised may well have been stripped of any qualifying considerations as they are reduced to bullet points and sound-bytes in the service of addressing urgent policy prerogatives. Talk about 'misbehaving policy' once referred to gender disappearing out of view: now it is much more likely to mean policy prescriptions and pieces of policy-speak that may be the inverse of what those who advocate for women's rights and empowerment may actually have wanted to see happen - part of what Ahikire 
calls 'success gone wrong'. As Takyiwaa Manuh reminded us at the workshop, while we talk about the extent to which Gender and Development has become depoliticised, we obscure the highly political nature of the way development actors and others beyond the sphere of 'development' - multinational corporations, banks, neo-conservatives, religious conservatives - are addressing women. All this comes into sharp relief when we consider the representations of women advanced by the neoliberal development establishment, and the ways that these representations reproduce entrenched stereotypes of women as the nurturing, selfsacrificing, hard-working heroes who will lift their families, communities and entire nations out of poverty (see, for example, de la Rocha 2007).

Revisioning feminist engagement calls not just for reflexivity and repositioning in these changing times, but also for much more canny appraisal of what it takes to make change happen. The essentially consensual line that has been pursued as part of a strategy for 'mainstreaming' gender strives not to ruffle any feathers or provoke any hostilities. As Ahikire reminds us, this has certainly achieved some gains in terms of the rhetoric we now hear from donors and lenders. But what have those shifts in language led to in the way of structural change? Fulsome rhetoric about the importance of women's empowerment is all around us, but when it comes to looking at the share of budgets that are being spent on any of the things that we've come to recognise as critical to empowerment interventions, we see that donors are far less willing to put money into following through.

If we look at what women are doing when they organise themselves, for themselves, we are likely to see much less of the kinds of compliance that are associated with development projects and

\section{Notes}

* We owe a huge thank you to Jenny Edwards for all her work supporting the production of this IDS Bulletin, and to Jenny, Julie McWilliam and Patsy Tayler at IDS for all their contributions to managing the logistics of the workshop from which this IDS Bulletin is derived. Alison Norwood deserves a medal for her patience which was tested to the limits, in waiting for us to complete this collection; we are immensely grateful to her programmes. Ironically, perhaps, Gender and Development has served to domesticate dissent rather than to lend those women who would challenge the status quo the support with which to do it. Fear of being labelled 'feminist' has acted as a powerful prophylactic, preventing those working within development frameworks from 'doing gender, thinking feminism' (Ahikire) rather than 'doing gender rather than feminism' (Sardenberg). Yet we also see, as Uma Chakravarti's article so vividly highlights, women mobilising within such projects and programmes to resist the established order, exposing the innate contradictions of these initiatives in the process.

Challenging and potentially transforming existing relations of power involves not only empowerment but also resistance: the two are inextricably intertwined. More often than not, this resistance runs directly counter to the neoliberal model, demanding the redistribution of resources, challenging the operation of markets, or organising against state repression. To conceive of empowerment in this way is to reveal the contradiction at the heart of development's interventions in this field: for all the talk about empowerment, there are few development agencies which would be prepared to support women mobilising in these ways. When women engage in struggles for transformation, they take part in a process of challenging and changing the very norms of behaviour that are reinforced by neoliberal development. To reclaim feminist concepts like 'agency' and 'empowerment', we need to return to and reaffirm their 'liberating' dimensions, reasserting their association with forms of collective action that involve possibilities of social transformation. The debates thrown up by this diverse and stimulating collection of articles suggest that this process has already begun.

for all that she has done to get this IDS Bulletin into print. Lastly, we'd like to thank the UK Government's Department for International Development (DFID) for funding to the Pathways of Empowerment Research Programme Consortium that made the workshop, and this publication, possible.

1 www.pathways-of-empowerment.org, accessed 24 October 2008 


\section{References}

Alsop, R. (ed.) (2005) Power, Rights and Poverty: Concepts and Connections, Washington DC: World Bank

Alsop, R.; Heinsohn, N. and Somma, A. (2005) 'Measuring Empowerment: An Analytic Approach', in R. Alsop (ed.), Power, Rights and Poverty: Concepts and Connections, Washington DC: World Bank

Alvarez, S. (1998) 'The 'NGOisation of Latin American Feminisms', in S. Alvarez, E. Dagnino and A. Escobar (eds), Cultures of Politics, Politics of Cultures: Re-visioning Latin American Social Movements, Boulder, CO: Westview

Batliwala, S. (2007) 'Taking the Power Out of Empowerment - An Experiential Account', Development in Practice 17.4 and 5: 557-65

Batliwala, S. and Dhanraj, D. (2004) 'Myths that Instrumentalise Women: Stories from the Indian Frontline', IDS Bulletin 35.5: 11-18

Bedford, K. (2005) 'Loving to Straighten out Development: Sexuality and "Ethnodevelopment" in the World Bank's Ecuadorian Lending', Feminist Legal Studies 13.3: 295-322

Buvinic, M. and King, E.M. (2007) 'Smart Economics', Finance and Development 44.2: 7-12

Cornwall, A. (2007) 'Pathways of Women's Empowerment', Open Democracy, 30 July, www.opendemocracy.net/article/pathways_of_ womens_empowerment (accessed 17 October 2008)

Cornwall, A.; Harrison, E. and Whitehead, A. (2007) 'Gender Myths and Feminist Fables: The Struggle for Interpretive Power in Gender and Development', Development and Change 38: 1-20

DFID (2007) Gender Equality at the Heart of Development, London: Department for International Development, www.dfid.gov.uk/Pubs/files/ gender-equality.pdf (accessed 24 October 2008)

Elson, D. (1992) 'Male Bias in Structural Adjustment', in H. Afshar and C. Dennis (eds), Women and Adjustment Policies in the Third World, New York: St Martin's

Griffin, P. (2006) 'Sexing the Economy in a Neoliberal World Order: Neo-liberal Discourse and the $(\mathrm{Re})$ Production of Heteronormative Heterosexuality', British Journal of Politics and International Relations 9.2: 220-38

Hawkesworth, M. (2006) 'Feminists v. Feminization: Confronting the War Logics of the Bush Administration', Asteriskos 1/2: 117-42
Jackson, C. and Pearson, R. (eds) (1998) Feminist Visions of Development: Gender Analysis and Policy, London: Routledge

Jackson, S. (2006) 'Gender, Sexuality and Heterosexuality: The Complexity (and Limits) of Heteronormativity', Feminist Theory 7.1: 1105-21

Kabeer, N. (2008) Researching the Relationship Between Paid Work and Women's Empowerment: Complexities, Contradictions and Contestations, Pathways of Women's Empowerment Working Paper, www. pathways-of-empowerment.org/ research_empowering _pubs.html (accessed 24 October 2008)

Miraftab, F. (2004) 'Invited and Invented Spaces of Participation: Neoliberal Citizenship and Feminists' Expanded Notion of Politics', Wagadu 1: $1-7$

Moghadam, V. (2005) Globalizing Women: Transnational Feminist Networks, Baltimore: Johns Hopkins University Press

Mohanty, C. (1991) 'Under Western Eyes: Feminist Scholarship and Colonial Discourses', in C.T. Mohanty, A. Russo, and L. Torres (eds), Third-world Women and the Politics of Feminism, Bloomington: Indiana University Press

Molyneux, M. (2008) 'The "Neoliberal Turn" and the New Social Policy in Latin America: How Neoliberal, How New?', Development and Change 39.5: 775-97

Molyneux, M. (2006) 'Mothers at the Service of the New Poverty Agenda: Progresa/Oportunidades, Mexico's Conditional Transfer Programme', Social Policy and Administration 40.4: 425-49

Ogundipe-Leslie, M. (1994) Recreating Ourselves: African Women and Critical Transformations, Trenton, NJ: Africa World Press

de la Rocha, M. (2007) 'The Construction of the Myth of Survival', Development and Change 38.1: 45-66

Romano, J.O. (2002) 'Empoderamento: Recuperando a Questão do Poder no Combate à Pobreza', in J. Romano and M. Antunes (orgs.), Empoderamento e Direitos no Combate à Pobreza, Rio de Janeiro: ActionAid

Sparr, P. (ed.) (1995) Mortgaging Women's Lives: Feminist Critiques of Structural Adjustment, London: Zed Books

Stiglitz, J. (2008) 'The End of Neo-Liberalism', Daily News, Cairo, 7 July 